American Journal of Economics and Business Administration 1 (3): 243-250, 2009

ISSN 1945-5488

(C) 2009 Science Publications

\title{
Guised in Green: Uncloaking the Myth of World Trade Organization's Trade-Environment Harmony
}

\author{
Alimpan Chatterjee, Deya Bhattacharya and Sonali Banerjee \\ Kalinga Institute of Industrial Technology Law School, \\ Kalinga Institute of Industrial Technology University, Bhubaneshwar, India
}

\begin{abstract}
Problem statement: Over the past decade the World Trade Organization (WTO) has devoted considerable attention to the implementation of policies that work on the interplay of trade and environment by identifying several Multilateral Environment Agreements (MEAs) that have provisions for trade so that trade liberalization and environmental protection interact positively. However, the strategy of the WTO to bring trade and environment into harmony is only a mirage. Approach: This study delved into the conflicts between trade measures in MEAs and WTO rules and how WTO's strategy to control trade in order to protect and preserve the environment is just a myth. Results: Through this study, we uncloaked the myths about sustainable development that WTO and MEAs together claim to bring about and delineate how the WTO is primarily a trading organization and has no specific agreement on environment. The study, therefore, shows how the 'greening of the WTO' has only just been a fallacy and how a difference can be made by introducing clarity in the provisions of the MEAs. Conclusion: The findings suggested that both trade and environment are extremely imperative to the concept of development and it is a verity that one cannot be sacrificed for the other since both are equally important for the common cause of social welfare.
\end{abstract}

Key words: WTO, MEAs, trade, environment, sustainable development

\section{INTRODUCTION}

Part I: The twin notions of trade and environment, though considered to be the epicenters of the globalization debate, are in constant dissonance with each other. Much of this discord is because it reveals the conflictive relationship between two legitimate interests of the international community: The international protection of the environment (The environment "represents the living space, quality of life and the very health of human beings including generations unborn". The obligation to protect the environment is a norm of international law ${ }^{[13]}$. This has been clarified by the International Court of Justice (ICJ) in its historic opinion in Advisory Opinion Legality of the Threat or Use of Nuclear Weapons on 8th July, 1996) and the liberalization of international trade $\mathrm{e}^{[1]}$. Traditionally, economic growth and its ecological consequences had been treated as two completely different concepts in the broader paradigm of development ${ }^{[14,16]}$. Trade liberalization through trade, investment, transferring finance and capital is indeed an engine for development. It is known that increased market access is an essential element for economic growth and progress; however, recent times have been witness to the infinite damage to the environment because of augmented economic growth and this, in turn, has challenged the traditional development paradigm.

Today the model of development encloses within it, both the notions of trade and environment and envisions the harmonization of both. This synthesis of trade and environment came to be known as sustainable development in the Report of the Brundtland Commission called "Our Common Future ${ }^{[28]}$. Sustainable development is development that meets the needs of the present without compromising the ability of future generations to meet their own needs. It contains within it two key concepts:

The concept of 'needs', in particular the essential needs of the world's poor, to which overriding priority should be given; and the idea of limitations imposed by the state of technology and social organization on the environment's ability to meet present and future needs. Sustainable Development was an Endeavour to bridge the chasm between the concepts of trade and environment, which are considered completely at odds with each other. To think of it, this abyss between trade and its ecological consequences was not even noticed before the publication of Carson's silent spring and

Corresponding Author: Alimpan Chatterjee, Kalinga Institute of Industrial Technology Law School,

Kalinga Institute of Industrial Technology University, Bhubaneshwar, India 
meadow's ${ }^{[22]}$.The limits to growth ${ }^{[23]}$, which highlighted the various complex problems that unfettered industrialization had caused. Indeed, environmental protection was not a major issue when the General Agreements on Tariffs and Trade (GATT) was drawn up just after World War II. In fact, until the early 1970s, trade policymakers and environmental enthusiasts had hardly ever perceived that their realms were interconnected.

In the 1970s, environmental protection concerns were just coming into the forefront of domestic and international policy considerations. In 1972, the United Nations called an international Conference on the Human Environment (UNCHE), made it clear that the international community no longer consider environment, economic and social development policy objectives separately ${ }^{[24]}$. It also resulted in the Stockholm Declaration ${ }^{[29]}$ on the Human Environment which recognizes, in Principle 2, "The natural resources of the earth, including the air, water, land, flora and fauna and especially representative samples of natural ecosystems, must be safeguarded for the benefit of present and future generations through careful planning or management, as appropriate" and, in Principle 14, the need to reconcile conflicts "between the needs of development and the need to protect and improve the environment" and the creation of the United Nations Environment Programme and increased impetus to agree on certain Multilateral Environmental Agreements (MEAs) such as the 1973 Convention on International Trade in Endangered Species (CITES) (Convention on International Trade in Endangered Species of Wild Fauna and Flora (adopted March 3, 1973, entered into force July 1, 1975). In preparation for this conference, GATT members created the Working Group on Environmental Measures and International Trade (EMIT) in 1971. However, the EMIT group did not have its first conference until twenty years later before the 1992 United Nations Conference on Environment and Development (UNCED) was held in Rio de Janeiro, (also known as the Rio Earth Summit). The decision to have a Working Group Working Group on Environmental Measures and International Trade (EMIT) also contained the clause that the group would only convene at the request of GATT members. It was not until 1991 when the members of the European Free Trade Association (EFTA) asked for the EMIT Group to be convened. EFTA, at the time included Austria, Finland, Iceland, Liechtenstein, Norway, Sweden and Switzerland. EFTA referred to the upcoming 1992 United Nations Conference on Environment and Development (UNCED) and said GATT should contribute. A significant development was in 1983 when the United Nations convened the World Commission on Environment and Development to address the growing concern "about the accelerating deterioration of the human environment and natural resources and the consequences of that deterioration for economic and social development ${ }^{[2]}$ ". The Commission's report, entitled "Our Common Future" (also known as the Brundtland Report), coined the term "sustainable development".

The Rio Earth Summit emphasized on the role of international trade in combating poverty and protection of the environment. Principle 3 of the Declaration states that the right to development must be fulfilled so as to equitably meet developmental and environmental needs of present and future generations, while Principle 8 says that to achieve sustainable development and a higher quality of life for all people, States should reduce and eliminate unsustainable patterns of production and consumption and promote appropriate demographic policies $^{[18]}$. The Agenda $21^{[21]}$ was a programme that was adopted at the Rio Earth Summit; it was a comprehensive global blueprint of the plan of action of humanity's interaction with the natural environment. Chapter 2 of Agenda 21, entitled 'International Cooperation to Accelerate Sustainable Development in Developing Countries and Related Domestic Policies', manifested trade, environment and sustainable development linkage in its four programme areas:

- The promotion of sustainable development through trade liberalization

- Making trade and the environment mutually supportive

- The provision of adequate financial resources to developing countries and dealing with international trade

- The encouragement of macroeconomic policies conducive to environment and development ${ }^{[21]}$

The World Summit on Sustainable Development (WSSD) held in 2002 in Johannesburg to review the progress on the implantation of Agenda 21 a decade after the Earth Summit. Two key documents came out of the WSSD, the Johannesburg Declaration on Sustainable Development and the Johannesburg Plan of Implementation (JPOI). These documents represent the commitment to strengthening the UN approach to sustainable development. They also reflect an increasing recognition of the importance of a holistic approach to international crises through the UN framework. As Strachan and Roberts attest, the Declaration and JPOI 'deepen the integration of 
poverty, economic and social issues in to the international framework on sustainable development elaborated through the United Nations'.

In some ways, the WSSD bridged the gap between the United Nations and the World Trade Organization by implanting the outcomes of the Doha Ministerial Conference by the $\mathrm{WTO}^{[6]}$. The Doha Declaration of 2001 was a breakthrough in more ways than one. It provided a platform for the commencement for a fresh round of negotiations in the ongoing multilateral trade area; it also strengthened the resolve of the WTO to protect the environment while engaging the trade liberalization (The Preamble to the Doha Declaration reaffirmed the commitment of the parties to the objective of sustainable development as stated in the Preamble of the Agreement Establishing the WTO ('Marrakesh Agreement'). It further elaborated the rights of parties to: Tak[e] measures for the protection of human, animal or plant life or health, or of the environment at the levels it considers appropriate, subject to the requirement that they are not applied in a manner which would constitute a means of arbitrary or unjustifiable discrimination between countries where the same conditions prevail, or a disguised restriction on international trade and are otherwise in accordance with the provisions of the WTO Agreements). Most importantly, the Doha Declaration redefined the relationship between the WTO and the Multilateral Environmental Agreements (MEAs); it gave a completely different perspective of the tradeenvironment debate.

Part II: The World Trade Organization (WTO) has a commitment to "an open, non-discriminatory and equitable multilateral trading system on the one hand," and to "protection of the environment and the promotion of sustainable development on the other ${ }^{[7] " \text { ". }}$

In no area has the WTO's "democratic deficit" has been more striking, or more censured, than in the trade and environment conflict ${ }^{[19]}$. The Preamble to the WTO Agreement was based on the Preamble to the GATT, but a small change was made. This change in the Marrakesh Agreement establishing the World Trade Organization (WTO Agreement) and its annexes acted as the pivot to the initial "greening of the WTO"[3]. Whereas the GATT's Preamble recognizes that trade relations should be conducted with a view to listed objectives including 'developing the full use of resources of the world ...', the WTO's Preamble modifies this by recognizing among the listed objectives, 'allowing for the optimal use of the world's resources in accordance with the objective of sustainable development, seeking both to protect and preserve the environment and to enhance the means for doing so in a manner consistent with their respective needs and concerns at different levels of development' (Preamble of the Final Act of the 1986-1994 Uruguay Round of trade negotiations). Little did anyone know what legal impact this preambular language would have. In later years, governments, WTO adjudicators and WTO officials have exploited this ambiguity in the preambular language as a justification for a stronger environmental facet of the WTO.

The objective of GATT/WTO has been to liberalize trade among its contracting parties. It seeks to gain the ostensible benefits associated with comparative advantage, an economic theory holding that the world economy can achieve greater economic efficiency through trade liberalization ${ }^{[4]}$ and is considered to be the cornerstone of the GATT/WTO's trade liberalization objective. It should be kept in mind that trade barriers are the anathema of GATT/WTO advocates of international trade law since they are an enormous obstacle to the exploitation of comparative advantages efficient distribution of natural resources. Hence, trade barriers and discrimination are generally forbidden in trade agreements ${ }^{[8]}$.

The monumental tripod structure and constitution of the GATT/WTO is supported by three normative pillars: Articles I, III, XI. These three articles are the three core objectives of the GATT/WTO and are known as the most-favored-nation principle (The mostfavored-nation principle found in Article I mandates "any advantage, favor, privilege, or immunity" granted to one member Party must be granted to other members. It discourages partiality amongst Parties; if a nation imposes quantitative restrictions on imports or exports, it must apply them similarly to all nations); the national treatment principle (The national treatment principle, adopted in Article III, applies to internal restrictions on foreign goods--that is trade restrictions that operate after importation, such as taxes and restrictions on the sale of goods. National treatment describes the obligation a nation has to treat foreign goods in the same manner as it treats like domestic goods. It prohibits discrimination against foreign products unless there is some characteristic distinguishing the foreign product from like domestic products) and the prohibition on quantitative restrictions on imports and exports (Article XI, the quintessential GATT provision, adopts the third core objective; it prohibits quantitative restrictions on imports and exports. Any measure having a limiting effect on imports or exports will likely flout Article XI), respectively. While the European Council has groped its way towards achieving an articulation of relationships between the 
various sectors of law-economic, social and environmental $^{[10]}$, the WTO is rather vague about its "greening". The only endeavor by the WTO, a rather persistent but hesitant effort, to create a trade law framework that would resolve contradictions (The twin objectives of the WTO-trade without barriers as well as a sustainable development-express the conviction of the WTO advocates that "there should not be, nor need be, any policy contradiction" between the objectives. Preamble of the Marrakesh Agreement) between trade liberalization and environmental protection is the interpretation of Article XX (Article XX of GATT affirms the legal right of WTO Members to adopt measures that address environmental issues. The Article waives members of the obligation to apply fundamental commitments, particularly non-discrimination, in certain cases, through $\mathrm{XX}(\mathrm{b})$ necessary to protect human, animal or plant life or health; and $\mathrm{XX}(\mathrm{g})$ relating to the conservation of exhaustible natural resources if such measures are made effective in conjunction with restrictions on domestic production and consumption) of the GATT. For any trade measure to qualify as an exception under the chapeau of Article $\mathrm{XX}$, it must go through a two-pronged test. First, the restriction should not "constitute a means of arbitrary or unjustifiable discrimination between countries where same conditions prevail". Second it should not be a "disguised restriction on international trade" (GATT, supra note 2, art. XX). Traditionally, under the old GATT regime, environmental protection through multilateral environmental agreements (MEAs) fell under the realm of Article XX's chapeau. However, recently due to several panel rulings Article $\mathrm{XX}$ requires strict and broad applicability resulting in a plethora of conflicts between MEAs and WTO rules.

It should be noted that the WTO and the MEAs are completely separate entities. Moreover, they are two different legal systems that have different histories and objectives and though they operate in the same sphere, they target different policy goals. The majority of the actions taken in MEAs do not have trade implications and most of the decisions taken in the WTO hardly have any environmental implications ${ }^{[23]}$. Nevertheless, what is important is that both entities should have an articulate and coherent relationship and any possibility of clash between the two regimes should be avoided.

The relationship between WTO rules and MEAs would show fissures upon careful scrutiny; in fact, in a broad perspective, there are no "real" problems ${ }^{[9]}$. A very important fact that underlies the ubiquitous tradeenvironment debate and the possibility of clashes between the two international entities, WTO and
MEAs, is that while the global trade regime is capable of intimidating domestic environmental laws, it itself does not refer to any minimum environmental standards. The rationale behind this lies in the fact WTO law is based upon the assumption of a hierarchy where trade principles are supreme. An example of this could be cited through the delineation of a potential conflict between MEAs and WTO rules through the WTO perspective regarding Process and Production Methods (PPMs) (The implication of the panel's interpretation of GATT was that any law restricting imports on the basis of their process or production method ("PPM") would necessarily violate Articles III and XI unless the PPM affected the physical characteristics of the product $)^{[25]}$. The WTO does not differentiate products on the basis of their production, or the manner in which they have been manufactured. It treats all products which have the same physical form as "like".

Environmentalists, however, disagree with the WTO advocates. They argue that if one method of processing (such as a method of fishing for tuna) causes environmental damage ${ }^{[24]}$ (high levels of incidental kill of dolphin ${ }^{[26]}$ then an importer should be able to express preference for the product (tuna) processed in a way that does not cause environmental damage (caught using fishing methods that reduced the incidental kill of dolphin). The WTO, thus, prohibits discrimination on the basis of production methods of "like" products (Article 2.1 of the Agreement on Technical Barriers to Trade (the TBT Agreement) provides that "Members shall ensure that in respect of technical regulations, products imported from the territory of any Member shall be accorded treatment no less favorable than that accorded ... to like products originating in any other country ${ }^{[15]}$ since allowing exceptions to protect national policies and creating provisions for domestic environmental interests could enable governments to adopt non-trade goals. It would also mean using WTO to promote several social, public and environmental goals which would bring alterations to its intrinsic objective of providing a common economic forum and a globalised open trading system to its members. Another problem when no distinction is made between goods produced differentially is that countries that use technology and safety measures to protect the environment are at a disadvantageous position when compared to nations that use PPMs that have detrimental effects on the ecology. Increased expenses for environment-friendly PPMs act as a deterrent to the concept of sustainable development. 
Sustainable development requires both, ecological well-being as well as economic development. However, more often than not, the objectives of certain MEAs are completely at odds with the rules of the WTO. For example, the provisions in the Convention on International Trade in Endangered Species (CITES) and Montreal Protocol, which restricts the production and sale of Chlorofluorocarbons (CFCs) are considered to be illegal under the GATT/WTO. The preamble of the CITES states that "international cooperation is essential for the protection of certain species of wild fauna and flora against the over-exploitation through international trade" (Under the Convention, trade in species threatened with extinction (listed in Appendix I) and trade in species that may become endangered unless trade is strictly regulated (listed in Appendix II) must be authorized by export and import permits approved by the scientific authorities of the parties concerned. Trade in species that a party identifies as being subject to regulation within its own jurisdiction and requiring international cooperation to control trade requires an export permit authorized by the scientific authority of the party (Convention on International Trade in Endangered Species of Wild Fauna and Flora (CITES) treaty agreement $)^{[20]}$. The purpose of this agreement, therefore, is to purge the international market off the demand for a particular wildlife product and in turn, eliminating economic incentives to exploit certain species. The Montreal Protocol aims to reduce the production of ozone-depleting substances, especially Chlorofluorocarbons (CFCs) (Montreal Protocol on Substances that Deplete the Ozone Layer, Sept. 16, 1987). United Nations Framework Convention on Climate Change (adopted at the Rio Conference in 1992) and the Kyoto Protocol (adopted in December, 2007) is grappling with most complex environmental issues as it aims to stabilize the emissions of all greenhouse gases, such as carbon dioxide or methane. Though all the three aforementioned MEAs are agreed upon in most nations and highlight devastating environmental impacts, they violate the erstwhile GATT and also the new GATT/WTO regime established by the Uruguay Round since each of these MEAs employ trade restrictions in diverse forms against non-parties. Therefore, these MEAs could be challenged on grounds of violating GATT's Articles I and III and also the TBT and SPS agreements.

Gary P. Sampson states that at the grass root level, the potential problems that revolve around inconsistent measures in the trade and environment agreements could be divided into two groups. The first group covers trade-related measures taken by a party to an MEA against another party (both parties members of the WTO) and where the measure is not specifically provided for in the MEA itself, but is "justified" by the party taking the measure as necessary to achieve the objectives of the environment agreement. The necessity of this measure may be challenged by the party against which the measure is taken and this measure could contravene WTO rights and obligations. This, in turn, could result in a dispute concerning the legitimacy of the measure in terms of either the MEA or the WTO. The second group of problems relates to WTOinconsistent measures that are specifically provided for in an MEA and taken by a party to the MEA against a non-party. A conflict may arise if the measure is against a WTO member that challenges the legitimacy of the measure in the WTO dispute settlement process ${ }^{[5,12]}$.

A dispute as to the legality of provisions arising out of an implementation of MEA should in ordinary course be pursued under the MEA dispute resolution. As a result of which the MEA would do well to stipulate from the inception that in case of trade disputes arising out of it, such dispute will be settled under the MEA's provision. This would be beneficial in uniting both the objectives of trade and environment. But however the MEA lack an effective dispute resolution system which is further amalgamated by the MEA's emphasis on avoiding conflict. Absence of an effective resolution system in such case would mean that disputes often gravitate towards the WTO and because of the exclusive jurisdiction and binding nature of the WTO dispute settlement system which often attracts environmentally related suits that are not the province of the WTO dispute settlement panel. Such a scenario presents a contradiction in the sense that now trade officials are tasked with the job of determining whether measures beneficial for the environment are necessary or not ${ }^{[17]}$. A task neither trade officials nor environmentalist think should fall to the WTO.

Part III: Several mainstream theorists advocate a genuine reconciliation of the conflicting ethos of trade liberalization and environmental protection. There is no one approach that can be used to achieve a balance between the two; like the problems are of various types, their solutions should also be multi-pronged. In fact, there are a myriad of conflicts that lie in the grey area between hard scientific evidence and national sensitivity to a particular environmental issue. In view of this, many have called for a world environmental organization to parallel the WTO, something that could 
encourage the clustering of MEAs under its canopy; or indeed an environmental organization within the WTO and not just an institutional environmental body like the Committee on Trade and Environment (CTE) or the GATT Group on Environmental Measures and International Trade (EMIT). However, any environmental system brought within the WTO umbrella would inevitably continue to perceive environmental measures as disruptions to free trade.

One strategy to address inconsistencies between the regimes of the WTO and the MEAs is the cooperation and coordination of trade and environment policymaking. Though this approach has jagged edges and undefined boundaries, it could entail representatives of trade, environmental protection and developing as well as developed nations attending a series of negotiations. However, action should be taken based on these negotiations which are only just the preliminary step to reach the ultimate goal of reconciliation.

Another approach to allay the trade-environment friction is bringing about a change of forum, one that is completely impartial and has no egocentric interests in either regime, to adjudicate disputes involving the WTO rules and MEA trade measures. Lakshman Guruswamy has observed that MEAs are generally weak bodies of law ${ }^{[11]}$ and that the WTO's DSU (Dispute Settlement Understanding), more often than not, overpowers the MEAs. Hence, it is said that disputes could be referred the International Court of Justice (ICJ), or the settlement body of the MEA involved. It also seems reasonable that disputes that a dispute should be pursued under the MEAs (The report recommended that when a dispute between members occurs arising out of their responsibilities as parties to a MEA, they should "consider trying to resolve it through the dispute settlement mechanisms available under the MEA") ${ }^{[27,28]}$ as this would ensure the convergence of the objectives of the WTO and the MEAs, ruling out the problems that could occur due to overlapping jurisdictions. Also, it has been suggested that from their inception, MEAs should have stipulations on how to deal with a conflict arising out of the trade measures incorporated within it.

Alternative strategies include critical interpretation of Article XX as well as the Waiver Approach (A waiver would be granted by the GATT/WTO members to allow derogations from members' obligations for actions taken pursuant to the MEAs. It maybe specifically directed at a select group of named agreement or it could encompass all MEAs that use trade measures to accomplish their environmental objective. In order to secure a waiver regarding the MEAs, a member will have to demonstrate "exceptional circumstances" and generally obtain three-fourths of the members support for such action) and some people have also suggested measures to amend the GATT/WTO as to include provision could create a presumption of legitimacy for measures derived from MEAs. However, these strategies are extremely controversial and to a large extent, are paradoxical to WTO's core objectives of free trade through exploitation of comparative advantage.

\section{CONCLUSION}

The trade liberalization-environmental protection debate is a ubiquitous one, especially under the WTO's ambiguous rules. The Doha Declaration in 2001 redefined the relationship between the WTO and the MEAs (Paragraphs 31-33 of Doha Declaration are concerned with environmental issues. Paragraph 31 states that Members negotiate on: "(i) the relationship between existing WTO rules and specific trade obligations set out in multilateral environmental agreements (MEAs)". It continues to provide: "The negotiations shall be limited in scope to the applicability of such existing WTO rules as among parties to the MEA in question. The negotiations shall not prejudice the WTO rights of any Members that is not a party to the MEA in question..." See, text of Doha Ministerial Declaration, adopted on 14 November, 2001). However, despite repeated and hesitant efforts of the WTO to introduce sustainable development or the harmony of trade and environment is but a chimera. A question frequently asked is whether WTO and MEAs are "friends or foes" (Bill Krist, Neither Friends Nor Foes, But Neighbors An Introduction to the Relationship Between the WTO and MEAs, Trade and Environment, the WTO and MEAs: Facets of a Complex Relationship, March, 2001)-both as opposing forces fighting for primacy. However, it would be impossible to consider the WTO and MEAs as either friends or foes because as it has been argued earlier is that both trade liberalization and environmental protection are complementary for the paradigm of development. Therefore, their relationship is akin to a relationship between neighbors: They need 
to respect each other's jurisdictions; "good fences make better neighbors".

\section{REFERENCES}

1. Sindico, F., 2004. Unraveling the Trade and Environment Debate through Sustainable Development Law Principles. http://www.esilsedi.eu/english/pdf/Sindico.PDF

2. Dominic, A.G., 2009. International trade and the environment: What is the role of the WTO? Fordham Environ. Law Rev., 20: 197-226.

3. Charnovitz, S., 2007. The WTO'S environmental progress. J. Int. Econ. Law, 10: 685-706.

4. Winter, R.L., 2000. Reconciling the GATT and WTO with multilateral environmental agreements: Can we have our cake and eat it too? Colorado J. Int. Environ. Law Policy, 11: 223-250.

5. Sampson, G.P., 2005. The WTO and Sustainable Development. United Nations University Press, New York, ISBN: 9280811150, pp: 315.

6. Palmer, A. and R. Tarasofsky, 2007. The Doha round and beyond: Towards a lasting relationship between WTO and the international environmental regime. Chatham House and the Royal Institute of International Affairs.

7. Gaines, S., 2001. The WTO'S reading of the GATT article $\mathrm{xx}$ chapeau: A disguised restriction on environmental measures. Univ. Pennsylvania J. Int. Econ. Law, 22: 739-858.

8. Carranza, M.A.E., 2007. MEAs with trade measures and the WTO: Aiming toward sustainable development? Buffalo Environ. Law J., 15: 43-82.

9. Sampson, G.P., 2001. Effective multilateral environment agreements and why the WTO needs them. World Econ., 24: 1109-1134.

10. Steinberg, R.H., 1997. Trade-environment negotiations in the EU, NAFTA and WTO: Regional trajectories of rule development. Am. J. Int. Law., 91: 231- 275.

11. Guruswamy, L.D., 1998. Should UNCLOS or GATT/WTO decide trade and environment disputes? Minnesota J. Global Trade., 7: 287-321.

12. Sampson, G.P., 2005. The WTO and Sustainable Development. United Nations University Press, New York, ISBN: 92-808-1115-0, pp: 128-143.

13. Shaw, M.N., 2003. International Environmental Law. 5th Edn., Cambridge University Press, Cambridge, ISBN: 0-521-53183-7, pp: 753-809.

14. Alam, S., 2008. Sustainable Development and Free Trade: Institutional Approaches. Routledge Taylor and Francis Group, ISBN: 0-203-93606-X, pp: 288.
15. Patrick, F.J. and E.M. Arthur, 2005. The World Trade Organization: Legal, Economic and Political Analysis. Vol. 1, Springer Science Business Media, Inc., New York, ISBN: 0-387-22685-0, pp: 1615.

16. IISD, 2005. Environment and Trade: A Handbook. 2nd Edn., The United Nations Environment Programme Division of Technology, International Institute for Sustainable Development, Canada, ISBN: 1-895536-85-5, pp: 122.

17. Adil, N., M. Halle and R. Meléndez-Ortiz, 2007. Trade and Environment: A Resource Book. International Center for Trade and Sustainable Development, New York, ISBN: 978-1-89553699-7, pp: 251.

18. Rao, P.K., 2002. International Environmental Law and Economics. Blackwell Publishers, Great Britain, ISBN: 0-631-21893-9, pp: 339.

19. Dillon, S., 2002. International Trade and Economic Law and the European Union. Hart Publishing, Oxford, ISBN: 1-841-13113-X, pp: 391.

20. Environment Canada, 1974. Convention on international trade in endangered species of wild fauna and Flora (CITES). http://www.ec.gc.ca/international/multilat/specie_e.htm

21. United Nations, 1992. Agenda 21 adopted in the United Nations Conference on Environment and Development, Rio de Janerio, Brazil. http://www.un.org/esa/dsd/agenda21/res_agenda21 _02.shtml

22. Neil, C., 2007. The Politics of the Environment. 2nd Edn., Cambridge University Press, ISBN: 13: 978-0-511-27828-0, pp: 410.

23. Krist, B., 2001. Neither friends nor foes, but neighbors an introduction to the relationship between the WTO and MEAs, trade and environment, the WTO and MEAs: Facets of a complex relationship, March.

24. Trachtman, J.P., 1992. United states-restrictions on imports of tuna, No. DS21/R, 30 ILM 1594 (1991). Am. J. Int. Law, 86: 142-151. http://www.jstor.org/pss/2203145

25. Knox, J.H., 2004. The judicial resolution of conflicts between trade and the environment. Harvard Environ. Law Rev., 28: 2-78.

26. Greenpeace international, 2001. Safe trade in the 21st century. Greenpeace Comprehensive Proposals and Recommendations for the 4th Ministerial Conference of the World Trade Organization, Aug. 2001, Centre for International Environmental Law and Greenpeace International, September, Doha, pp: 1-20. http://archive.greenpeace.org/politics/wto/doha_rep ort.pdf 
27. WTO Committee, 1996. WTO Committee on Trade and the Environment, Report, 1996 of the Committee on Trade and the Environment.

28. UN Documents Gathering a Body of Global Agreements, 1987. Report of the world commission on environment and development: Our common future. http://www.undocuments.net/wced-ocf.htm
29. United Nations Environment Programme, 1972. Declaration of the United Nations Conference on the Human Environment. http://www.unep.org/Documents.Multilingual/Defa ult.asp?DocumentID=97\&ArticleID=1503 